\title{
Detection of Ehrlichia canis in domestic cats in the central-western region of Brazil
}

\author{
Ísis Assis Braga ${ }^{1,2}$, Luana Gabriela Ferreira dos Santos ${ }^{2}$, \\ Dirceu Guilherme de Souza Ramos ${ }^{1}$, Andréia Lima Tomé Melo ${ }^{1,2}$, \\ Gustavo Leandro da Cruz Mestre ${ }^{3}$, Daniel Moura de Aguiar ${ }^{2}$ \\ ${ }^{1}$ Programa de Pós-Graduação em Ciências Veterinárias, Faculdade de Agronomia, Medicina Veterinária e \\ Zootecnia, Universidade Federal de Mato Grosso, Cuiabá, MT, Brazil. \\ ${ }^{2}$ Laboratório de Virologia e Rickettsioses, Hospital Veterinário, Universidade Federal de Mato Grosso, \\ Cuiabá, MT, Brazil. \\ ${ }^{3}$ Centro de Controle de Zoonoses, Secretaria Municipal da Saúde de Cuiabá, Cuiabá, MT, Brazil.
}

Submitted: October 31, 2012; Approved: November 25, 2013.

\begin{abstract}
Ehrlichiosis is a worldwide distributed disease caused by different bacteria of the Ehrlichia genus that are transmitted by arthropod vectors. Its occurrence in dogs is considered endemic in several regions of Brazil. Regarding cats, however, few studies have been done and, consequently, there is not enough data available. In order to detect Ehrlichia spp. in cats from the central-western region of Brazil, blood and serum samples were collected from a regional population of 212 individuals originated from the cities of Cuiabá and Várzea Grande. These animals were tested by the Immunofluorescence Assay (IFA) and the Polymerase Chain Reaction (PCR) designed to amplify a 409 bp fragment of the $d s b$ gene. The results obtained show that 88 (41.5\%) cats were seropositive by IFA and $20(9.4 \%)$ cats were positive by PCR. The partial DNA sequence obtained from PCR products yielded twenty samples that were found to match perfectly the Ehrlichia canis sequences deposited on GenBank. The natural transmission of Ehrlichia in cats has not been fully established. Furthermore, tick infestation was not observed in the evaluated cats and was not observed any association between age, gender and positivity of cats in both tests. The present study reports the first serological and molecular detection of $E$. canis in domestic cats located in the endemic area previously mentioned.
\end{abstract}

Key words: Ehrlichiosis, feline, PCR, IFA, ticks.

\section{Introduction}

Ehrlichiosis is a worldwide distributed disease caused by microorganisms of Ehrlichia genus that is transmitted by arthropod vectors (Groves et al., 1975; Couto, 1998). Ehrlichia spp. belongs to the Rickettsiales order and the Anaplasmataceae family (Dumler et al., 2001; Paddock and Childs, 2003). It is an exclusive Gram-negative intracellular parasite, located in cytoplasmic vacuoles of mature or immature hematopoietic and endothelial cells, and found in peripheral blood or tissue (Unver et al., 2001).

Some domestic and wild mammals, such as canines and ruminants, are reservoirs of Ehrlichia spp., but domes- tic cats also can be considered as reservoirs for the agent and infection source for other animals, including humans (Stubbs et al., 2000). The first case of feline ehrlichiosis was described in the 80's (Charpentier and Groulade, 1986) and, since then, several cases of this ehrlichiosis have been reported (Stubbs et al., 2000). Ehrlichia species that naturally infect cats were not totally characterized. Few studies in order to clarify the Ehrlichia species that infect cats were conducted, but monocytic, lymphocytic and, granulocytic inclusions were detected in cats with febrile illness and thrombocytopenia suggesting that other rickettsial species could act on feline ehrlichiosis infection.

Send correspondence to D.M. Aguiar. Laboratório de Virologia e Rickettsioses, Hospital Veterinário, Universidade Federal de Mato Grosso, Av. Fernando Corrêa 2367, Boa Esperança, 78060-900 Cuiabá, MT, Brazil. E-mail: danmoura@ufmt.br. 
In Brazil, Ehrlichia infection was first reported by Almosny and Massard (1999) throughout the observation of ehrlichial morula in blood smears, and in 2009 it was first detected by PCR by Oliveira et al. (2009), both studies accomplished in southeast region of Brazil. Recently, Braga et al. (2010) reported the first surveillance of feline ehrlichiosis in a free-living, healthy cat population in the northeast region of Brazil.

In addition, natural transmission of Ehrlichia in cats has not been fully established (Amyx and Huxsoll, 1997). However, Rhipicephalus sanguineus tick demonstrates wide geographical distribution in Brazilian urban areas (Labruna and Pereira, 2001) and it was previously reported in cats from the northeast region of Brazil (Ferreira et al., 2009; Ferreira et al., 2010), what suggests the transmission of Ehrlichia by R. sanguineus.

This study investigates the presence of Ehrlichia spp. in domestic cats from the metropolitan region of Cuiabá, which is an endemic area to these bacteria in Mato Grosso state.

\section{Materials and Methods}

Between May and December 2011, 212 whole blood EDTA and serum samples were collected from domestic cats. The samples were collected in animals originally from the Zoonosis Control Center (ZCC) in Cuiabá (1535'56" S $\left.56^{\circ} 06^{\prime} 01^{\prime \prime} \mathrm{W}\right)$ and in Várzea Grande $\left(15^{\circ} 38^{\prime} 49^{\prime \prime} \mathrm{S}\right.$; $56^{\circ} 07^{\prime} 58^{\prime \prime}$ W) cities (IBGE, 2010) (Figure 1), from animals treated in the Veterinary Hospital of the Federal University of Mato Grosso State (HOVET-UFMT) and also from animals that lived in a shelter for dogs and cats. All samples were stored at $-20{ }^{\circ} \mathrm{C}$ until analysis. Samples collection was in agreement with the Ethical Principles for Animal Research established by the Brazilian Society of Science in Animals of Laboratory (SBCAL) under the institutional Committee for Ethics in Animal Research (protocol number UFMT 23108.017751/11-7).

The collected blood samples were subjected to a DNA extraction using the Axyprep Blood Genomic DNA Miniprep Kit (Axygen Biosciences, Zhejiang Province, Hangzhou, China). The DNA was then used as a template for a PCR assay with primers $d s b-330$ (5'- GAT GAT GTC TGA AGA TAT GAA ACA AAT $-3^{\prime}$ ) and $d s b-728$ (5'CTG CTC GTC TAT TTT ACT TCT TAA AGT -3'), designed to amplify a 409-bp fragment of the $d s b$ gene of Ehrlichia spp., following Doyle et al. (2005). PCR negative control (ultrapure - MilliQ ${ }^{\circledR}$ ) and positive control (DNA from São Paulo strain of E. canis obtained from DH82 culture) were used in each reaction.

After that, amplicons were purified using illustra GFX PCR DNA and Gel Band Purification Kit (GE Healthcare Bio-Sciences, England, Buckinghamshire, UK), and subjected to DNA sequencing using the Big Dye Kit (Applied Biosystems/Perkin Elmer, Foster City, California, USA) on an ABI-PRISM 3100 Genetic Analyzer.
Both products were used in accordance with the manufacturer's instructions. The sequences were evaluated using the SeqMan software (Lasergene, DNAstar, Madison, WI USA.) and similarity was analyzed using the program Basic Local Alignment Search Tool (BLAST) (Altschul et al., 1990) to check for homology with corresponding sequences available on GenBank.

The presence of anti-Ehrlichia spp. antibodies was evaluated by the Immunofluorescence Assay (IFA) using São Paulo strain of $E$. canis as antigen with a cut-off point at an initial dilution of 1:40 (Aguirre et al., 2004). Commercial fluorescein isothiocyanate-conjugated anti-cat $\operatorname{IgG}$ (Sigma-Aldrich, Saint Louis, Missouri) was used as conjugate at dilution of 1:1000. The antigen preparation and the IFA were executed as previously described (Aguiar et al., 2007). For IFA standardization, serums of PCR positive cats were tested to be used as positive control and a previously non-reactive serum (negative control) was included in each assay.

Data concerning age, sex and tick parasitism in cats were used for risk factor analysis. To define age, cats with corporal mass less than $1.5 \mathrm{~kg}$ were considered young and cats weighing $1.5 \mathrm{~kg}$ or more were considered adults based on their dental arcade, according to study of Sharif et al. (2007).

The association between Ehrlichia spp. infection in cats and independent variables was performed by QuiSquare test $\left(\chi^{2}\right)$ or Fisher exact test when applicable. Analysis of the association among different IFA endpoint titers and positive or negative PCR cats were performed by Wilcoxon test. The statistical software EPIINFO 3.5.3 was used for this analysis and $p \leq 0.05$ was considered significant.

\section{Results}

Among the 212 evaluated cats, 93 (43.8\%) of the samples were from HOVET, 31 (14.7\%) were from the mentioned shelter, $23(10.8 \%)$ and $65(30.7 \%)$ were from the ZCC of Cuiabá and Várzea Grande, respectively. One hundred two animals (48.1\%) were female and 110 $(51.9 \%)$ male. Fifty nine $(28.6 \%)$ were young and 147 $(71.4 \%)$ were adult. Age information was not available for six cats.

Twenty (9.4\%) cats were PCR positive for Ehrlichia spp. and nucleotide sequences generated in PCR were identical to each other and between sequences of $E$. canis Uberlandia (GU586135) and E. canis str. Jake (CP000107), deposited on Genbank. According to their origin, 8 (2.6\%) positive cats were from HOVET, 1 (4.3\%) from the ZCC of Cuiabá and 11 (16.9\%) from the ZCC of Várzea Grande. No samples from shelter cats were positive on PCR $(\mathrm{p} \leq 0.05)$. Eight $(40.0 \%)$ of the positive animals were young and $12(60.0 \%)$ were adults $(\mathrm{p}>0.05)$. Both gender 


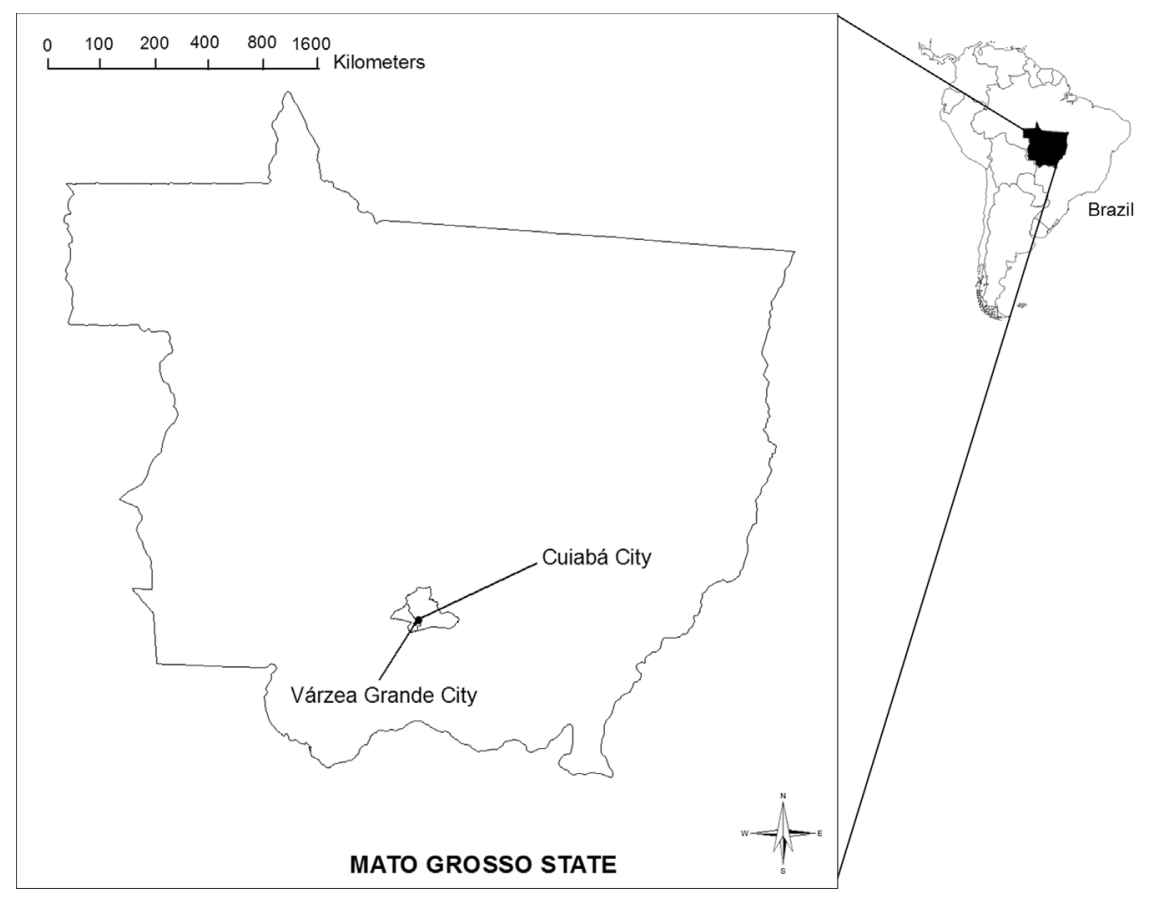

Figure 1 - Location of Cuiabá and Várzea Grande cities, Mato Grosso State. Cuiabá, 2013.

had the same proportion $(50.0 \% ; \mathrm{p}>0.05)$ of positive samples.

Serologic tests resulted in $88(41.5 \%)$ seropositive cats for E. canis. Forty-two $(45.1 \%)$ cats were from HOVET, 3 (13.0\%) from the ZCC of Cuiabá, 27 (41.5\%) from the ZCC of Várzea Grande and 16 (51.6\%) from the shelter $(\mathrm{p} \leq 0.05)$. Twenty-six $(31.7 \%)$ cats were young and $59(71.9 \%)$ were adults. Forty-five $(51.1 \%)$ seroposive samples were from female and 43 (48.9\%) from male animals $(\mathrm{p}>0.05)$. Antibody titers ranged from 40 to 40960 . Two cats (2.2\%) had titers of $40,14(16.0 \%)$ cats of 80,31 $(35.2 \%)$ of $160,15(17.0 \%)$ of $320,14(16.0 \%)$ of 640,10 (11.4\%) of 1280 , one $(1.1 \%)$ of 10240 , and one $(1.1 \%)$ of 40960. No significant association was observed between IFA antibodies titles and PCR result.

Twelve (5.6\%) cats were positive for both molecular and serological tests and eight PCR-positive cats were negative by serology $(p>0.05)$. No ticks were found in the evaluated cats.

\section{Discussion}

Research about the presence of Ehrlichia spp. in domestic cats has been conducted in some countries, such as Spain (Aguirre et al., 2004), Sweden (Bjoersdorff et al., 1999), France (Beaufils et al., 1995), United States (Bouloy et al., 1994), and Kenya (Buoro et al., 1989). In particular, the present study detected the highest frequency of Ehrlichia spp. infection in domestic cats in Brazil.

Seroprevalence detected evidence of exposure to Ehrlichia spp. in a feline population in the central-western region of Brazil. However, the occurrence of cross-reac- tivity with other Anaplasmataceae family agents cannot be ruled out (Wen et al., 1997). Amplified DNA samples analyzed by sequencing reactions were identical to the sequences of $E$. canis available on GenBank, what suggests that a single strain of $E$. canis was infecting dogs and cats, collaborating with the findings of Oliveira et al. (2009). The central-western region of Brazil was considered to be endemic for E. canis in dogs (Silva et al., 2010; Sousa et al., 2010; Melo et al., 2011). Furthermore, E. canis DNA was detected in $R$. sanguineus ticks, assuming potential risk factor for the disease (Almeida et al., 2012).

Ehrlichia is transmitted through the bite of an infected tick, mainly in tropical and subtropical regions (Rodriguez-Vivas et al., 2005). Although tick exposure has been reported in about $30 \%$ of feline ehrlichiosis cases (Lappin, 2001), reports of $R$. sanguineus parasitism in cats are rare, probably due to their licking habit and to common prophylactic measures (Breitschwerdt et al., 2002). Moreover, the absence of ticks in the evaluated cats can suggest the existence of an unknown vector acting as the transmission agent in cats.

Negative PCR results in seropositive cats show the lack of E. canis in peripheral blood, during subclinical or chronic phases of the disease, despite their presence in spleen or other lymphoid tissue (Eberhardt et al., 2006). However no association was found among different IFA antibody endpoint titers and PCR positive or negative cats. Little is known about the dynamics of $E$. canis infection in cats, so any presumption about rickettsemia in cats is speculative. The positive result in both tests leads to the assumption that these animals were possibly in the acute or 
asymptomatic phase of the infection, corresponding to the period of seroconversion. Other potential hypothesis is that these animals would be through a period of resurgence as a result of immunosuppression.

No association between age and sex was found, minimizing the effect of social behavior in the epidemiology of infection in the considered region. These results are similar to the findings of Stubbs et al. (2000) related to age, except that they found gender predominance with higher female positivity.

Regarding the origin of cats, animals from the $\mathrm{ZCC}$ Várzea Grande had a higher frequency of positive PCR and the second highest frequency of anti-E. canis antibodies. This fact is probably due to the peculiar characteristics of the area, which contribute to expose these animals to infection. Shelter cats had a higher frequency of anti-E. canis antibodies, what implies that these animals were more exposed to the agent, possibly by being in direct contact with $R$. sanguineus of infected dogs. Nevertheless the study contributes to other studies that suggest the role of domestic cats as reservoirs of $E$. canis.

\section{Acknowledgments}

We are very gratefull to A.J. Mendonça and L. Nakazato for making available the Clinical Veterinary Pathology and Molecular Biology Laboratories to our research. We thank C. Bulla (Department of Pathobiology and Population Medicine, Mississippi State University, EUA) for the technical support and thoughtful review of the manuscript. This work was supported by Fundação de Amparo à Pesquisa do Estado de Mato Grosso (FAPEMAT) and Conselho Nacional de Desenvolvimento Científico e Tecnológico (CNPQ). Scholarships were provided by Coordenação de Aperfeiçoamento Pessoal de Nível Superior (CAPES) for IAB, LGFS and DGSR and CNPQ for the academic career scholarship to DMA.

\section{References}

Aguiar DM, Saito TB, Hagiwara MK, Machado RZ, Labruna MB (2007) Diagnóstico sorológico de erliquiose canina com antígeno brasileiro de Ehrlichia canis. Cienc Rural 37:796802.

Aguirre E, Tesouro MA, Amusategui I, Rodríguez-Franco F, Sainz A (2004) Assessment of feline ehrlichiosis in central spain using serology and a polymerase chain reaction technique. Ann NY Acad Sci 1026:103-105.

Almeida ABPF, Paula DAJ, Dahroug MAA, Freitas AG, Silva JN, Dutra V, Nakazato L, Sousa VRF (2012) Ehrlichia canis e Anaplasma platys em carrapatos de cães de Cuiabá, Mato Grosso. Semina Ciênc Agrar 23:1123-1126.

Almosny NRP, Massard CL (1999) Feline ehrlichiosis-review. Clin Vet 4:30-32.

Altschul SF, Gish W, Miller W, Myers EW (1990) Basic local alinment search tool. J Mol Biol 215:403-410.

Amyx HL, Huxsoll DL (1997) Red and gray foxes - Potential reservoir hosts for Ehrlichia canis. J Wild Dis 9:47-50.
Beaufils JP, Marin-Granel J, Jumelle P (1995) Ehrlichia infection in cats: a review of three cases. Prat Med Chir Anim Comp 30:397-402.

Bjoersdorff A, Svendenius L, Owens JH, Massung RF (1999) Feline granulocytic ehrlichiosis: a report of a new clinical entity and characterization of the new infectious agent. J Small Anim Pract 40:20-24.

Bouloy RP, Lappin MR, Holland CH, Thrall MA, Baker D, O'Neil S (1994) Clinical ehrlichiosis in a cat. J Am Vet Med Assoc 204:1475-1478.

Buoro IBJ, Atwel RB, Kiptoon JC, Ihiga MA (1989) Feline anemia associated with Ehrlichia-like bodies in three domestic shorthaired cats Vet Rec 125:434-436.

Braga MSCO, André MR, Fresch CR, Teixeira MCA, Machado RZ (2010) Molecular and serological detection of Ehrlichia spp. in cats on São Luís Island, Maranhão, Brazil. Rev Bras Parasitol Vet 21:37-41.

Breitschwerdt EB, Abrams-Ogg ACG, Lappin MR, Bienzle D, Hancock SI, Cowan SM, Clooten JK, Hegarty BC, Hawkins EC (2002) Molecular evidence supporting Ehrlichia canislike infection in cats. J Vet Intern Med 16:642-649.

Charpentier F, Groulade P (1986) Report of one case of probable feline ehrlichiosis. Bull Acad Vet Fr 59:287-290.

Couto CG, (1998) Doenças rickettsiais. In: Birchard, S.J., Sherding, R.G. (eds) Manual Saunders: Clínica de Pequenos Animais. Roca, São Paulo, pp 139-142.

Doyle CK, Labruna MB, Breitschwerdt EB, Tang YW, Corstvet RE, Hegarty BC, Bloch KC, Li P, Walker DH, McBride JW (2005) Detection of medically important Ehrlichia by quantitative multicolor taqman real-time polymerase chain reaction of the $d s b$ gene. J Mol Diagn 7:504-510.

Dumler JS, Barbet AF, Bekker CP, Dasch GA, Palmer GH, Ray SC, Rikihisa Y, Rurangirwa FR (2001) Reorganization of genera in the families Rickettsiaceae and Anaplasmataceae in the order Rickettsiales: Unification of some species of Ehrlichia with Anaplasma, Cowdria with Ehrlichia and Ehrlichia with Neorickettsia, descriptions of six new species combinations and designation of Ehrlichia equi and 'HGE agent' as subjective synonyms of Ehrlichia phagocytophila. Int J Syst Evol Microbiol 51:2145-2165.

Eberhardt JM, Neal K, Shackelford T, Lappin MR (2006) Prevalence of selected infectious disease agents in cats from arizona. J Feline Med Surg 8:164-168.

Ferreira CGT, Bezerra ACDS, Filgueira KDF, Fonseca ZAAS, Ahid SMM (2009) Levantamento de ectoparasitas de cães e gatos provenientes do município de Mossoró, Rio Grande do Norte, Brasil. PUBVET, http://www.pubvet.com.br/artigos_det.asp? artigo $=91$.

Ferreira DRA, Alves LC Faustino MAG (2010) Ectoparasitos de Felis catus domesticus (Linnaeus, 1758) na cidade de João Pessoa, Paraíba, Brasil. Rev Biotemas 23:43-50.

Groves, MG, Dennis GL, Amyx HL, Huxsoll DL (1975) Transmission of Ehrlichia canis to dogs by ticks (Rhipicephalus sanguineus). Am J Vet Res 36:937-940.

Instituto Brasileiro de Geografia e Estatística (IBGE), 2010. IBGE Cidades @. Available from: http://www.ibge.gov.br/cidadesat/topwindow.htm1.

Labruna MB, Pereira MC (2001) Carrapatos em cães no Brasil. Clin Vet 30:24-32.

Lappin M, (2001). Feline ehrlichiosis and hemobartonellosis. In: Scherk M. (ed). Proceedings of the 26th World Small Ani- 
mal Veterinary Association World Congress, Vancouver, BC. http://www.vin.com/VINDBPud/SearchPB/Proceeding/PR05000/PR00111.htm.

Melo ALT, Martins TF, Horta MC, Moraes-Filho J, Pacheco RC, Labruna MB, Aguiar DM (2011) Seroprevalence and risk factors to Ehrlichia spp. and Rickettsia spp. in dogs from the Pantanal Region of Mato Grosso State, Brazil. Ticks Tick Borne Dis 2:213-218.

Oliveira LS, Mourão LC, Oliveira KA, Agostini MM, Oliveira AC, Almeida MR, Fietto JLR, Conceição LG, Filho JDR, Galvão MAM, Mafra C (2009) Molecular detection of Ehrlichia canis in cats in Brazil. Clin Microbiol Infec 15:53-54.

Paddock CD, Childs JE (2003) Ehrlichia chaffeensis: A prototypical emerging pathogen. Clin Microbiol Rev 16:37-64.

Rodriguez-Vivas RI, Albornoz REF, Bolio GME (2005) Ehrlichia canis in dogs in Yucatan, Mexico: Seroprevalence, prevalence of infection and associated factors. Vet Parasitol 127:75-79.

Sharif M, Nasrolahei M, Ziapour SP, Gholami S, Ziaei H, Daryani D, Khalilian A (2007) Toxocara cati infections in stray cats in northern Iran. J Helminthol 81:63-66.
Silva JN, Almeida ABPF, Boa Sorte E, Freitas AG, Santos LGF, Aguiar DM, Sousa VRF (2010) Soroprevalência de anticorpos anti-Ehrlichia canis em cães de Cuiabá, Mato Grosso. Rev Bras Parasitol Vet 19:102-111.

Sousa VRF, Almeida ABPF, Barros LA, Sales KG, Justino CHS, Dalcin L, Bomfim TCB (2010) Avaliação clínica e molecular de cães com erliquiose. Cienc Rural 40:1309-1313.

Stubbs CJ, Holland CJ, Relf JS, Bruns C, Wheeler S, Lappin MR (2000) Feline ehrlichiosis. Comp Cont Educ Pract 22:307318.

Unver A, Perez M, Orellana N, Huang H, Rikihisa Y (2001) Molecular and antigenic comparison of Ehrlichia canis isolates from dogs, ticks, and a human in Venezuela. J Clin Microbiol 39:2788-2793.

Wen B, Rikihisa Y, Mott JM, Greene R, Kim HY, Zhi N, Couto GC, Unver A, Bartsch R (1997) Comparison of Nested PCR with Immunofluorescent-Antibody Assay for Detection of Ehrlichia canis Infection in Dogs Treats with Doxycycline. J Clin Microbiol 35:1852-1855.

All the content of the journal, except where otherwise noted, is licensed under a Creative Commons License CC BY-NC. 